\title{
Indolent Systemic Mastocytosis - a Case Report
}

\author{
Ljuba VUJANOVIĆ1*, Marina JOVANOVIĆ1, Zoran GOLUŠIN1, Olivera LEVAKOV1, \\ Aleksandra PETROVIĆ², Jasmina SEKULIĆ
}

${ }^{1}$ Clinic of Dermatovenereology Diseases, Clinical Center of Vojvodina, Novi Sad, Serbia, University of Novi Sad, Faculty of Medicine, Novi Sad, Serbia

${ }^{2}$ Løvåsen sykehjem Undervisningssykehjem, Bergen, Norway

"General Hospital "Đorđe Joanović" Zrenjanin, Serbia

*Correspondence: Ljuba Vujanović, E-mail: ljuba.vujanovic@mf.uns.ac.rs

UDC 616.515:[616-008.9:577.125

\begin{abstract}
Indolent systemic mastocytosis is a benign form of systemic mastocytosis characterized by an abnormal proliferation of mast cells either in the bone marrow or in numerous tissues. Case Report: A 27-year-old female patient was admitted to our department due to urticaria which started a month ago. Before the skin changes appeared, our patient suffered from a toothache, so she took various painkillers (nimesulide, ibuprofen, acetylsalicylic acid, paracetamol). During skin examination, individual hyperpigmented macules on the trunk and lower limbs were observed as incidental findings. The patient reported having them for the last two years. Darier's sign was positive. Following the examination, she was admitted due to suspected urticaria pigmentosa. Laboratory Findings: erythrocyte sedimentation rate: $9 \mathrm{~mm} / \mathrm{h}$; complete blood count, urine, blood glucose, total and direct bilirubin, aspartate aminotransferase, alanine aminotransferase, gamma-glutamyl transferase, urea, creatinine, and uric acid were within normal ranges. Electrolytes: sodium, potassium, chlorine clearance, total calcium and calcium ionized, osteocalcin, and crosslaps were within normal ranges as well. Fibrinogen: $5.57 \mathrm{~g} / \mathrm{l}$; 5-Hydroxyindoleacetic acid: $49.8 \mathrm{umol} / \mathrm{dU}$ (10.4 - 31.2). Bone densitometry, chest x-ray and upper abdomen ultrasound findings were normal. The suspected clinical diagnosis of urticaria pigmentosa was confirmed by skin biopsy. Histopathological examination of the bone marrow showed moderately increased cellularity (60 - 70\%). All three types of blood cells were slightly multiplied. Focal infiltrations were found in the perivascular area, consisting of elongated, oval cells with abundant eosinophilic granular cytoplasm. The nuclei were regular, oval shaped with finely granular chromatin and inconspicuous nucleoli. No nuclear atypia was found. These cells are highly CD117-positive. This finding strongly indicated bone marrow infiltration in systemic mastocytosis. The diagnosis was based on 'major' and 'minor' diagnostic criteria. The recommended therapy included $\mathrm{H} 1$ and $\mathrm{H} 2$ antagonists and topical corticosteroids. Conclusion: Regular follow-up was recommended in order to prevent complications and malignant alterations.
\end{abstract}

Key words: Mastocytosis, Systemic; Mastocytosis, Cutaneous; Urticaria Pigmentosa; Diagnosis; Signs and Symptoms; Histamine H1 Antagonists; Histamine H2 Antagonists; Dermatologic Agents; Case Reports

Mastocytosis is defined as a heterogeneous group of hematopoietic disorders characterized by increased accumulation of mast cells in one or more organs $(1,2)$. The classification of the World Health Organization (WHO) classifies it into cutaneous and systemic mastocytosis (3). The clinical presentations and the course of mastocytosis are variable, ranging from pure cutaneous mastocytosis (CM) to different forms of systemic mastocytosis (SM).

In 1869, Nettleship and Tay described a rare form of urticaria with pigmented papular lesions, later termed as urticaria pigmentosa by Sangster in 1878. After mast cells were described by Paul Ehrlich in 1879, the disease was classified as mastocytosis. Until 1949, it was believed that mastocytosis was only a cutaneous disease, but then Ellis described involvement of visceral organs as well (4).

Systemic mastocytosis is a disease of unknown etiology, characterized by abnormal proliferation of mast cells. Skin is the most commonly involved organ, but bone marrow, liver, spleen, lymph nodes and some other organs may be involved as well $(5,6)$. 


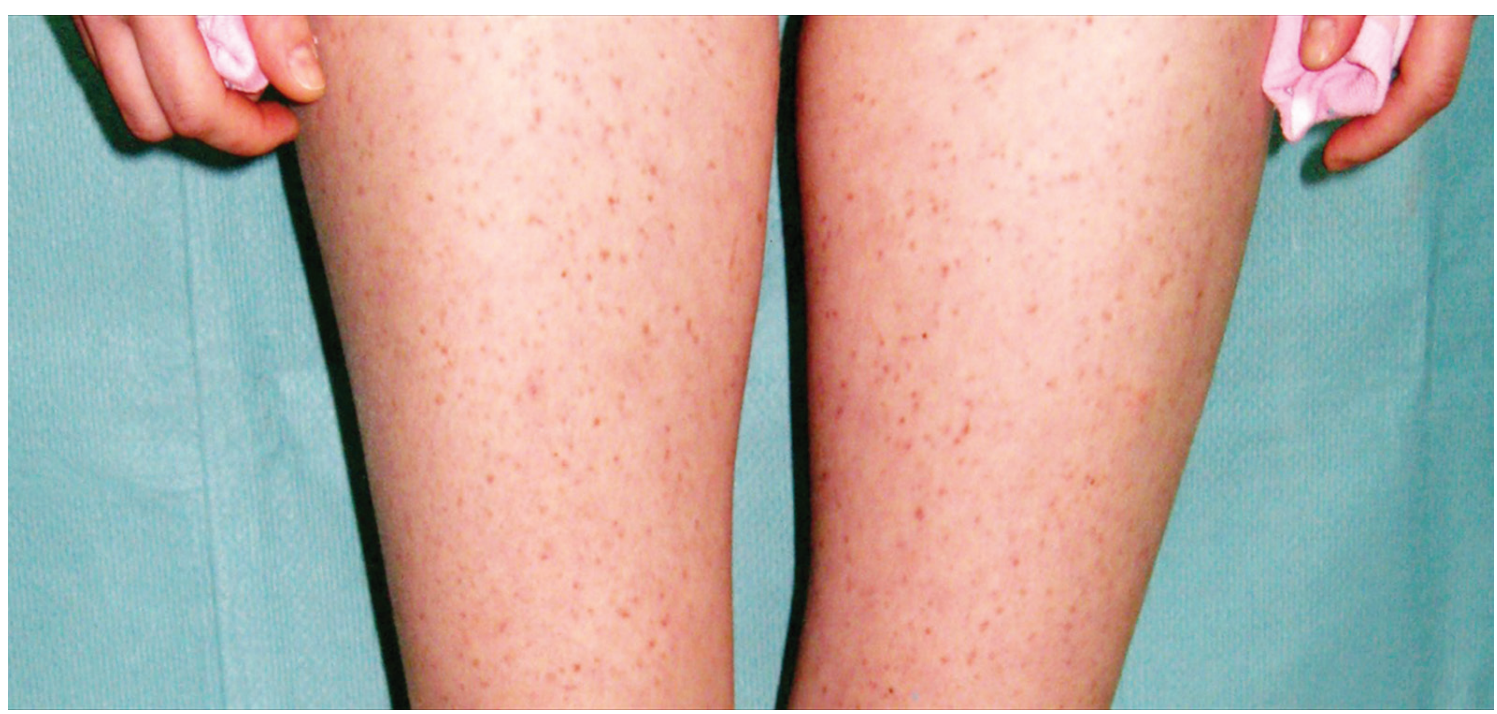

Figure 1. Hyperpigmented macules on the lower limbs

\section{Case Report}

A 27-year-old female patient was referred to a dermatologist due to onset of acute urticaria after taking non-steroidal anti-inflammatory drugs. During skin examination, individual hyperpigmented macules on the trunk and lower limbs were observed as an incidental finding. The patient reported having them for the last two years. Darier's sign was positive (Figure 1).

Relevant laboratory tests and diagnostic procedures were run, as urticaria pigmentosa was suspected. Laboratory findings: erythrocyte sedimentation rate (ESR): $9 \mathrm{~mm} / \mathrm{h}$; complete blood count (CBC), urine, blood glucose (BG); total and direct bilirubin, aspartate aminotransferase (AST), alanine aminotransferase (ALT), gamma-glutamyl transferase (GGT), urea, creatinine, and uric acid were within normal ranges. Electrolytes: sodium $(\mathrm{Na})$, potassium $(\mathrm{K})$, chlorine clearance $(\mathrm{Cl})$, total calcium and calcium ionized; osteocalcin, crosslaps were within normal ranges as well. Fibrinogen: $5.57 \mathrm{~g} / \mathrm{l} ; 5$-Hydroxyindoleacetic acid (5-HIAA): $49.8 \mathrm{umol} / \mathrm{dU}$ (10.4 - 31.2). Bone densitometry, chest x-ray and upper abdomen ultrasound findings were normal.

Histopathology of the skin showed diffuse hyperkeratotic epidermis. Perivascular infiltration of the upper dermis consisted of moderate mononuclear inflammatory infiltrates with increased number of spindle mast cells. Adnexal atrophy was observed. Sweat glands were of normal appearance and distribution (Figure 2, 3). Histopathology of the bone marrow showed increased cellularity $(60-70 \%)$ with moderate reduction of fat tissue. All three types of blood cells were present, preserved continuity of maturation and distribution, slightly multiplied. Megakaryocytes were individual and polymorphic. The granulocyte lineage was moderately hyperplastic, without maturation disorders and with slight domination of neutrophil granulocytes. Erythrocyte lineage was formed of large normoblastic islands, with preserved maturation and morphology. Small round lymphocytes and plasmocytes had an interstitial distribution.

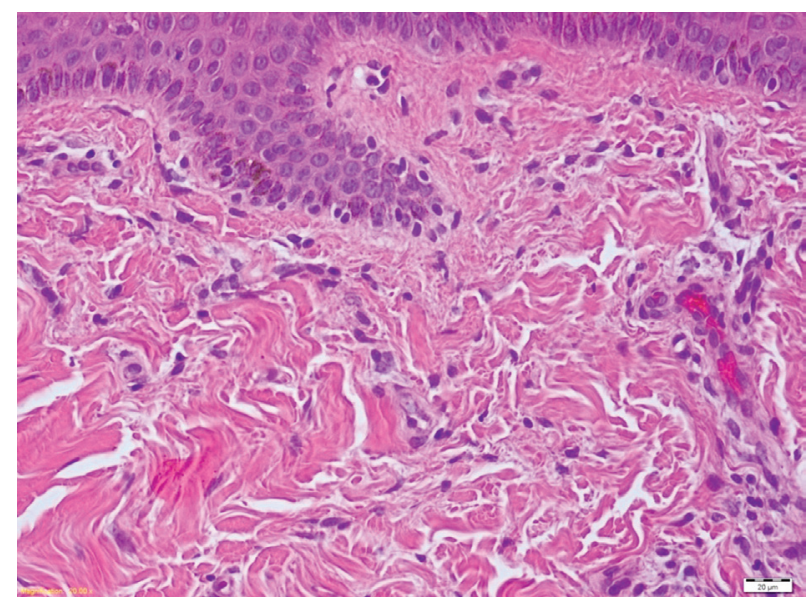

Figure 2. Perivascular infiltration of the upper dermis consisted of moderate mononuclear inflammatory infiltrate 


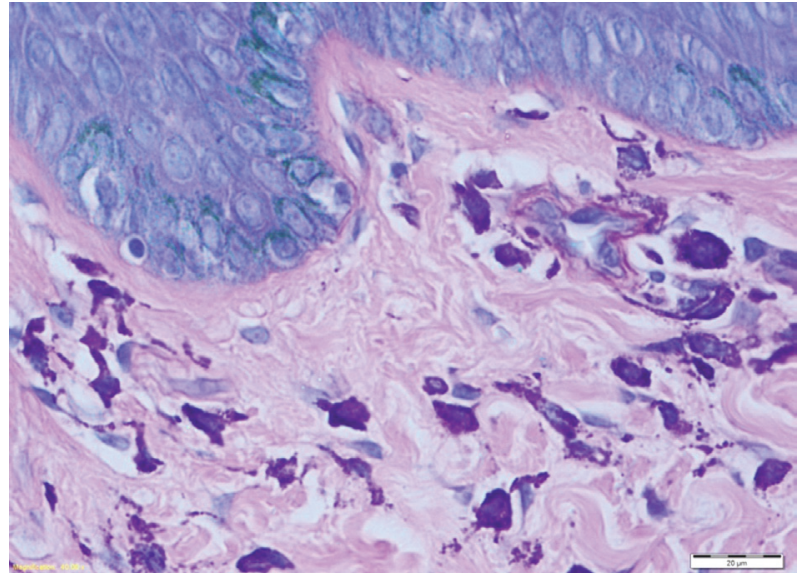

Figure 3. Perivascular infiltration of the upper dermis consisted of moderate mononuclear inflammatory infiltrate with increased number of spindle mast cells

A focal infiltration pattern was detected in the perivascular area, consisting of elongated, oval cells with abundant eosinophilic granular cytoplasm. The nuclei were regular, oval shaped with finely granular chromatin and inconspicuous nucleoli. No nuclear atypia was found. These cells were highly CD 117-positive. In addition to already described cells, morphologically, mastocytes, small round lymphocytes, eosinophils, and some plasmocytes were observed. This finding strongly indicated bone marrow infiltration in systemic mastocytosis. Oral antihistamines and topical corticosteroids were administered. The patient did not report for regular check up.

\section{Discussion}

In 2008, WHO classified mastocytosis as a subtype of myeloproliferative neoplasms. It was divided in two main types, cutaneous and systemic, and classified into different subtypes. Subtypes of cutaneous mastocytosis are urticaria pigmentosa, maculopapular cutaneous mastocytosis, diffuse cutaneous mastocytosis, and mastocytoma of the skin. Subtypes of systemic mastocytosis are indolent systemic mastocytosis, systemic mastocytosis with an associated hematologic nonmast cell lineage disease, aggressive systemic mastocytosis, mast cell leukemia, mast cell sarcoma, mast cell sarcoma and extracutaneous mastocytoma (3). For dermatologists, the points of interest are cutaneous mastocytosis without bone marrow involvement and indolent systemic mastocytosis, including bone marrow involvement and cutaneous symptoms (8). Mastocyte activation subsequently triggers pruritus, erythema, urticaria, abdominal pain, diarrhea, and psychiatric disorders $(6,8)$. Our patient complained of itching. Mastocyte degranulation is stimulated by heat, cold, pressure, bacterial toxins, drugs (aspirin, codeine, morphine) $(6,9)$. Our patient was taking various nonsteroidal anti-inflammatory drugs, including acetylsalicylic acid due to toothache. Systemic indolent mastocytosis is a benign form of systemic mastocytosis characterized by an abnormal proliferation of mast cells only in the bone marrow or in numerous tissues. In our patient mast cell proliferation was observed in the skin and in the bone marrow.

The diagnosis was based on diagnostic criteria (according to WHO classification). One major criterion was fulfilled (multifocal aggregates of mast cells in bone marrow biopsy specimen) and one minor criterion (atypical morphology in more than $25 \%$ mast cells in skin biopsy specimen). Also, the diagnosis can be established if at least three minor criteria are fulfulled - more than $25 \%$ of mast cells in the bone marrow or other extracutaneous organs show abnormal morphology or are spindleshaped, KIT mutation at codon 816 in extracutaneous organs, KIT + mast cells in bone marrow show aberrant expression of CD2 and/or CD25 and serum total tryptase $>20 \mathrm{ng} / \mathrm{ml}$ (10).

The aim of mastocytosis therapy is to remove or reduce the symptoms. Since there is no specific therapy, and having pruritus as a main symptom, systemic antihistamines and topical corticosteroids were administered. Success of the therapy remained unknown, because our patient has not reported for regular check ups ever since. In addition to already described therapy, if the symptoms affect the quality of life, different therapeutic modalities may be applied, such as leukotriene antagonists, corticosteroids, PUVA therapy. A severe form of indolent systemic mastocytosis was treated by inhibitors of tyrosine kinase and imatinib mesylate with good therapeutic response (Marton et al., Akin et al., Hoffman et al., Ustun et al.) $(7,11,12,13)$. Although positive outcome of systemic mastocytosis is expected, extremely rare, aggressive form may develop. 


\section{Conclusion}

This case report presents a female patient with a rare presentation of indolent systemic mastocytosis. Due to possible, although rare, development of aggressive forms of the disease, regular check ups, including upper abdomen ultrasound examination and serum tryptase level evaluation, as well as regular follow ups were recommended.

\section{Abbreviations}

CA - calcium

ESR - erythrocyte sedimentation rate

CBC - complete blood count

AST - aspartate aminotransferase

ALT - alanine aminotransferase

GGT - gamma-glutamyl transferase

$\mathrm{Na}$ - sodium

$\mathrm{K}$ - potassium

$\mathrm{Cl}$ - chlorine clearance

5-HIAA - 5-Hydroxyindoleacetic acid

WHO - World Health Organization

$\mathrm{CM}$ - cutaneous mastocytosis

SM - systemic mastocytosis

PUVA - psoralen and ultraviolet $A$

\section{References}

1. Mehta S, Masatkar V, Khare AK, Mittal A, Gupta LK. Blaschkoid mastocytosis. Indian J Dermatol Venereol Leprol. 2015;81(1):72-3.

2. Metcalfe DD. Mast cell and mastocytosis. Blood. 2008;112(4):946-56.

3. Horny HP. Mastocytosis. In: Swerdlow S, Campo E, Harris NL, Jaffe ES, Pileri SA, Stein H, et al, editors. WHO classification of tumours of haematopoietic and lymphoid tissues. Lyon: International Agensy for Research and Cancer (IARC); 2008. p. 54-63.

4. Janjua SA. Mastocytosis: from Nettleship and Darier to Metcalfe and Valent. Journal of Pakistan Association of Dermatologist. 2004;14:1-4.

5. Demis DJ. The mastocytosis sydrome: clinical and biological studies. Ann Intern Med. 1963;59(2):194206.

6. Saikam S, Narahari A, Anisha M, Hanumanthayya $\mathrm{K}$, Priya JT. A case report of indolent systemic mastocytosis. Journal of Evidence Based Medicine and Healthcare. 2016;3(36):1798-800.

7. Marton I, Posfai E, Borbenyi Z, Bodor C, Papp G, Demeter J, et al. Therapeutic challenge during the long-term follow-up of a patient with indolent systemic mastocytosis with extensive cutaneous involvement. Eur Rev Med Pharmacol Sci. 2015;19(9):1607-9.

8. Somani VK, Sharma VK, Sita VN, Razvi F, Sucharita V. Congenital multiple cutaneous mastocytoma. Indian J Dermatol Venereol Leprol. 1996;62(3):175-7.

9. Nayak S, Acharjya B, Devi B, Behera SK. Bullous mastocytosis. Indian J Dermatol. 2007;52(4):201-3.

10. Fritsche-Polanz R, Jordan JH, Feix A, Sperr WR, Sunder-Plassmann G, Valent $P$, et al. Mutation analysis of C-KIT in patients with myelodysplastic syndromes without mastocytosis and case of systemic mastocytosis. Br J Haematol. 2001;113(2):357-64.

11. Akin C, Fumo G, Yavuz AS, Lipsky PE, Neckers L, Metcalfe DD. A novel form of mastocytosis associated with a transmembrane c-kit mutation and response to imatinib. Blood. 2004;103(8):3222-5.

12. Hoffmann KM, Moser A, Lohse P, Winkler A, Binder $B$, Sovinz $P$, et al. Successful treatment of progressive cutaneous mastocytosis with imatinib in a 2-year-old boy carrying a somatic KIT mutation. Blood 2008;112(5):1655-7.

13. Ustun C, DeRemer DL, Akin C. Tyrosine kinase inhibitors in the treatment of systemic mastocytosis. Leuk Res. 2011;35(9):1143-52.

\section{Indolentna sistemska mastocitoza - prikaz slučaja}

\section{Sažetak}

Indolentna sistemska mastocitoza je benigna forma sistemske mastocitoze za koju je karakteristična abnormalna proliferacija mast ćelija samo u koštanoj srži ili i u drugim organima. Bolesnica, stara 27 godina, došla je na pregled zbog urtikarije koja se javila mesec dana ranije. Pojavi kožnih promena prethodila je zubobolja zbog koje je koristila veći broj analgetika (nimesulid, ibuprofen, acetilsalicilnu kiselinu, paracetamol). Prilikom pregleda, kao usputan nalaz, uočavaju se pojedinačne hiperpigmentovane makule na trupu i donjim ekstremitetima. Anamnestički je dobijen podatak o pojavi ovih promena unazad dve godine. Darijerov znak je bio pozitivan. Hospitalizovana je zbog sumnje na urtikariju pigmentoza (Urticaria pigmentosa). Laboratorijski nalazi: SE: $9 \mathrm{~mm} / \mathrm{h}, \mathrm{KKS}$, urin, ŠUK, bilirubini, AST, ALT, GGT, urea, kreatinin, ac. urikum u granicama referentnih vrednosti. Elektroliti: $\mathrm{Na}, \mathrm{K}, \mathrm{Cl}, \mathrm{Ca}, \mathrm{Ca}$ jonizovani, osteokalcin, Kroslaps u granicama referentne vrednosti, fi- 
brinogen 5,57g/l; 5- HIAA: 49,8 umol/dU (10,4-31,2). Denzitometrija kostiju, RTG pluća, ultrasonografski nalaz gornjeg abdomena u granicama referentnih vrednosti. Patohistološki nalaz bioptata kože ukazivao je na klinički postavljenu dijagnozu - Urticaria pigmentosa. Patohistološki nalaz biopsije koštane srži: umereno povećane celularnosti (60-70\%). Sve tri loze su lako umnožene. Perivaskularno, na par mesta postoji infiltrat koji se sastoji od izduženih, ovalnih ćelija, obilne, eozino- filne, diskretno granulirane citoplazme. Jedra su pravilna, ovalna, fino granuliranog hromatina, neupadljivog nukleusa, bez atipije. Ove ćelije su izrazito CD117+. Nalaz najviše odgovara infiltraciji koštane srži u sklopu sistemske mastocitoze. Dijagnoza je postavljena na osnovu major i minor dijagnostičkih kriterijuma. Terapija: H1 i H2 antagonisti i topikalno kortikosteroidi. Zaključak. Neophodne su redovne kontrole i praćenje bolesnika zbog mogućih komplikacija i maligne transformacije.

Ključne reči: Sistemska mastocitoza; Kutana mastocitoza; Urticaria pigmentosa; Dijagnoza; Znaci i simptomi; Histaminski H1 antagonisti; Histaminski H2 antagonisti; Dermatološki agensi; Prikazi slučajeva 